\title{
Composition, functional properties and antioxidative activity of hydrolysates prepared from the frame meat of Striped catfish (Pangasianodon hypophthalmus)
}

\author{
S. Tanuja ${ }^{* 1,2}$, P. Viji ${ }^{1}$, A.A. Zynudheen ${ }^{1}$ \& C.G. Joshy ${ }^{1}$ \\ 1 Fish Processing Division, Central Institute of Fisheries Technology, Matsyapuri P.O, Willington Island, \\ Cochin, India 682029. \\ 2 Directorate of Research on Women in Agriculture, Bharatpur Square, Nandan Kanan Khandagiri Road,
} Baramunda, Bhubaneswar, India 751003

\begin{abstract}
The Striped catfish Pangasianodon hypophthalmus has increasing importance as a candidate for aquaculture in India. It is an abundant and underutilized resource that can be used as a unique protein source to make Fish Protein Hydrolysates. The objective of the present study was to prepare protein hydrolysates from its frame meat using the neutral proteases Papain and Bromelain at $0.5 \%(\mathrm{w} / \mathrm{w})$ concentration to compare the composition, functional and antioxidative properties. The yield and degree of hydrolysis did not differ significantly between the two proteases. Hydrolysate prepared with papain had a higher crude protein and ash content. They differed significantly in foaming, emulsification and peptide solubility, with papain better in foaming capacity and peptide solubility, and bromelain better in emulsification capacity. Both exhibited almost $90 \%$ radical scavenging capacity, and differed significantly in reducing capacity. Thus hydrolysates produced with these proteases vary in their nutritional, functional and antioxidant characteristics.
\end{abstract}

Keywords: degree of hydrolysis, DPPH radical-scavenging capacity, reducing capacity, metal-chelating capacity, foaming capacity, emulsifying capacity, oil-binding capacity.

\section{Introduction}

Large amounts of protein-rich by-products (including head, frame meat, viscera, skin bone and some muscle tissue) are discarded every year from seafood processing plants without any attempt at recovery or else they get converted into low-market-value products such as fishmeal or fertilizer. Recovering fish muscle proteins from processing waste and converting it into high-end products is timely. Not only does it serve as an opportunity for increasing revenue but also the much-needed purpose of reducing environmental pollution. An interesting possibility is to hydrolyze the waste to obtain fish protein hydrolysates with desirable functional and antioxidant properties.

Chemical and biological methods can be used for the production of hydrolysates. Protein hydrolysis with strong chemicals and solvents is performed at extreme temperatures and $\mathrm{pH}$, and generally yields products with reduced nutritional qualities, poor functionality, and hence restricted in use as flavour enhancers. Thus enzymatic modification of proteins using selected proteolytic enzymes to cleave specific peptide bonds is more frequently used in the food industry to produce hydrolysates with excellent functional properties (Quaglia \& Orban 1990). Digestion parameters such as time, temperature and $\mathrm{pH}$ are tightly controlled to produce fish protein hydrolysates with the desired functional and nutritional properties, balanced amino acid composition and high digestibility. Protein hydrolysates are produced for a wide variety of uses in the food industry, including milk replacers, animal food, media for growing microorganisms, protein supplements, stabilizers in beverages and flavour enhancers in confectionery products. A number of scientific journals have cited the antioxidative and antiproliferative activity of fish protein hydrolysate, which makes it eligible for listing as a nutraceutical (Krisstinsson \& Rasco 2000)

\footnotetext{
* Author for correspondence: email : tanujasomarajan@gmail.com Fax: 06742386242
} 
Presently catfish farming is gaining importance among Indian farmers as an alternative to carp in different parts of the country; accordingly its contribution to overall fish production is on the rise. Pangasianodon hypophthalmus, popularly referred to as Pangasius or Striped catfish, is a prime species farmed in Vietnam and other Southeast Asian countries. It was first introduced to India in West Bengal in 1995. In 2000, the species was introduced into Andhra Pradesh. Because of its remarkable growth rate (almost one $\mathrm{kg}$ in 90 days), there has been much enthusiasm among fish breeders and farmers particularly in West Bengal and Andhra Pradesh for its culture and propagation. High nutritional quality and excellent sensory properties have made this species preferable among consumers. The processing wastes of viscera, skin, scales, bones, frame meat, etc., can be converted into useful by-products. Of these, the filleting waste can be used as an excellent raw material for hydrolysate production.

There is little information regarding protein hydrolysates from the meat of Striped catfish, and their antioxidative activity and functional properties when different enzymes are used. Hence the aim of this study was to produce protein hydrolysate from the frame meat using two different neutral proteases (Papain and Bromelain), and to study differences in yield, composition, functional properties and antioxidative activity.

\section{Materials \& Methods}

Meat was collected and cooked from catfish frame samples from a farm near Kodungallur, Kerala. The meat was packed in polythene bags, blast-frozen and maintained at $-20{ }^{0} \mathrm{C}$ until used in the hydrolysis experiments. The meat was cooked to inactivate endogenous enzymes. The cooked meat was minced and samples of $50 \mathrm{gm}$ suspended in distilled water in 1:1 ratio. The $\mathrm{pH}$ and temperature of the mixture was adjusted for optimum enzyme activity (pH 7.0 and $60{ }^{\circ} \mathrm{C}$ for papain, 7.0 and $55{ }^{\circ} \mathrm{C}$ for bromelain) and maintained at constant levels. The mixtures were pre-incubated at these temperatures for $20 \mathrm{~min}$ prior to the addition of enzymes in a controlled water bath (Nulab, Germany). Protein hydrolysis was initiated by the addition of the enzymes at $0.5 \% \mathrm{w} / \mathrm{w}$ of the protein content in the mince. The enzymatic hydrolysis proceded for 90 min with continuous stirring, and then enzyme activity was terminated by keeping the mixture in a water bath for $30 \mathrm{~min}$ at $90{ }^{\circ} \mathrm{C}$ (papain) or $85{ }^{\circ} \mathrm{C}$ (bromelain). When the mixture was cool it was filtered and centrifuged at $10000 \mathrm{rpm}$ for $15 \mathrm{~min}$ (Hermle Z36HK). The supernatant was collected and vacuum-dried (Heraeus Vacutherm, Germany). The samples were sealed in laminated pouches and kept at $4{ }^{0} \mathrm{C}$ for further experiments.

Yield was calculated as a percentage of the substrate concentration. Moisture, protein, fat and ash content were determined according to AOAC (2000) methods. The degree of hydrolysis was determined by the TNBS method (Benjakul \& Morrissey 1997). Amino acids in the vacuum-dried hydrolysates were analysed according to Ishida et al. (1981), quantifying the amino acids (except tryptophan).

Among the functional properties studied, solubility of protein hydrolysates were determined by the Nitrogen Solubility Index (Morr et al. 1985). The emulsifying capacity was studied following the method of Swift \& Sulzbacher (1963) with some modifications. $200 \mathrm{mg}$ of hydrolysate sample was dissolved in $0.1 \mathrm{M} \mathrm{NaCl}$. The mixture was homogenized for $20 \mathrm{sec}$ and weighed. Oil was added to the suspension at a flow rate of $0.5 \mathrm{ml} / \mathrm{sec}$. A multimeter was used to measure the maximum resistance point achieved. The difference in weight was measured, and emulsifying capacity expressed as $\mathrm{ml}$ oil/g sample by correcting for oil density $(0.9112 \mathrm{~g} / \mathrm{l})$. The foaming ability was expressed as foam expansion at $1 \mathrm{~min}$ (Lawhon et al. 1972). The oil-binding capacity was measured following the procedure of Shahidi et al (1995).

For the determination of antioxidant activity, the 2,2-diphenyl-1picrylhydrazyl (DPPH) radical scavenging activity (Shimada et al. 1992), metal-chelating capacity (Decker \& Welch 1990) and reducing capacity (Yildrim et al. 2001) were measured. 
All treatments were run in triplicate, and the mean and standard deviation of each treatment with respect to the parameters calculated. The parametric t-test was used to compare the effect of the two treatments (papain and bromelain) on the composition, functional and antioxidant properties of hydrolysate prepared from frame meat of Striped catfish. SAS 9.2 statistical software was used for data analysis. Significance was set at 0.05 .

\section{Results}

Differences in the average degree of hydrolysis (Fig. 1) and yield of hydrolysate (Fig. 2) produced with the neutral proteases papain and bromelain were not significant.

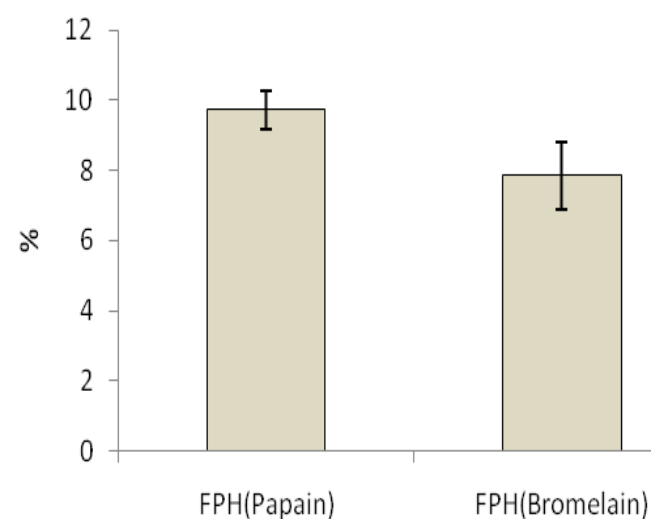

Fig 1: Effect of two different neutral proteases papain and bromelain on the degree of hydrolysis (\%) of Striped catfish protein hydrolysate. $(n=3, t=1.70, d f=4, p=0.16)$

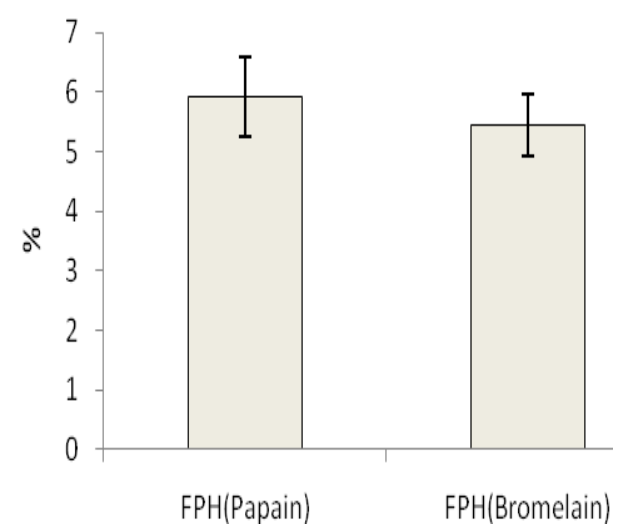

Fig 2: Effect of two different neutral proteases papain and bromelain on the yield $(\%)$ of Striped catfish protein hydrolysate. $(\mathrm{n}=3, \mathrm{t}=0.58, \mathrm{df}=4, \mathrm{p}=0.59)$

\begin{tabular}{|c|c|c|c|c|c|}
\hline \multirow[t]{2}{*}{$\begin{array}{l}\text { Proximate } \\
\text { composition }(\%)\end{array}$} & \multicolumn{2}{|c|}{$\begin{array}{l}\text { Fish protein hydrolysate } \\
\text { from }\end{array}$} & \multirow[t]{2}{*}{$\mathbf{t}$} & \multirow[t]{2}{*}{ df } & \multirow[t]{2}{*}{$\mathbf{p}$} \\
\hline & papain & bromelain & & & \\
\hline Moisture & $5.97 \pm 0.49$ & $4.81 \pm 1.23$ & 1.51 & 4 & 0.21 \\
\hline Crude protein & $92.12 \pm 0.59$ & $84.33 \pm 3.64$ & 3.66 & 4 & 0.02 \\
\hline Fat & $0.61 \pm 0.03$ & $1.09 \pm 0.78$ & 1.41 & 4 & 0.23 \\
\hline Ash & $6.26 \pm 0.11$ & $4.79 \pm 0.37$ & 6.56 & 4 & 0.003 \\
\hline
\end{tabular}

Table 1: Proximate composition of Striped catfish protein hydrolysate prepared with enzymes papain and bromelain. Values represent mean \pm SD of three replicates.

Table 1 shows the proximate composition of the hydrolysates prepared with papain and bromelain. Hydrolysate from papain had a significantly higher crude protein and ash content compared to hydrolysate from bromelain. The hydrolysate produced with both enzymes showed good protein recovery, low moisture content and low fat content. 


\begin{tabular}{|c|c|c|}
\hline \multirow[t]{2}{*}{ Amino acid (\%) } & \multicolumn{2}{|c|}{ Fish protein hydrolysate from } \\
\hline & papain & bromelain \\
\hline Taurine & $0.57 \pm 0.18$ & $0.96 \pm 0.32$ \\
\hline Aspartic acid & $7.52 \pm 1.20$ & $10.48 \pm 0.44$ \\
\hline Threonine & $3.66 \pm 0.44$ & $3.95 \pm 1.30$ \\
\hline Serine & $4.26 \pm 0.26$ & $6.22 \pm 0.13$ \\
\hline Glutamic & $10.73 \pm 0.40$ & $16.06 \pm 0.92$ \\
\hline Proline & $0.95 \pm 0.20$ & $1.27 \pm 0.31$ \\
\hline Glycine & $5.19 \pm 0.44$ & $7.58 \pm 0.89$ \\
\hline Alanine & $7.16 \pm 0.64$ & $9.03 \pm 0.80$ \\
\hline Valine & $8.09 \pm 0.38$ & $5.17 \pm 0.79$ \\
\hline Methionine & $2.02 \pm 0.79$ & $4.61 \pm 1.10$ \\
\hline Leucine & $8.11 \pm 0.06$ & $9.14 \pm 0.30$ \\
\hline Tyrosine & $0.55 \pm 0.30$ & $0.67 \pm 0.10$ \\
\hline Phenylalanine & $1.69 \pm 0.34$ & $2.47 \pm 0.40$ \\
\hline Histidine & $8.38 \pm 0.37$ & $7.65 \pm 2.00$ \\
\hline Lysine & $24.76 \pm 0.88$ & $3.64 \pm 1.31$ \\
\hline Arginine & $14.80 \pm 0.30$ & $7.41 \pm 2.24$ \\
\hline
\end{tabular}

Table 2: Amino acid composition of Striped catfish protein hydrolysate prepared with enzymes papain and bromelain. Values reperesent mean $\pm \mathrm{SD}$ of three replicates.

The amino acid content of hydrolysate from papain and from bromelain are very similar except for lysine and arginine (Table 2). The ratio of essential to non-essential amino acids were 1.98 (from papain) and 0.87 (from bromelain). Hydrolysate from papain showed a higher lysine and arginine content.

Table 3 shows the functional properties of the hydrolysates. The hydrolysates prepared with the two different proteases differed significantly in all the functional properties studied except for oil binding capacity. The hydrolysates exhibited good solubility $(>65 \%)$ and emulsification capacity $(>76 \%)$, but low foaming capacity $(<24 \%)$.

\begin{tabular}{|c|c|c|c|c|c|}
\hline \multirow[t]{2}{*}{ Functional properties } & \multicolumn{2}{|c|}{$\begin{array}{l}\text { Fish protein hydrolysate } \\
\text { from }\end{array}$} & \multirow[t]{2}{*}{$\mathbf{t}$} & \multirow[t]{2}{*}{ df } & \multirow[t]{2}{*}{ p value } \\
\hline & papain & bromelain & & & \\
\hline Foaming capacity $(\%)$ & $23.33 \pm 1.15$ & $17.33 \pm 1.15$ & 6.36 & 4 & 0.003 \\
\hline Emulsifying capacity ( $\mathrm{ml}$ oil/200 mg hydrolysate) & $76.45 \pm 1.69$ & $85.41 \pm 4.89$ & 3.00 & 4 & 0.04 \\
\hline Peptide solubility (\%) & $83.11 \pm 0.53$ & $64.92 \pm 2.84$ & 0.88 & 4 & $<0.001$ \\
\hline Oil binding capacity ( $\mathrm{ml} \mathrm{oil} / \mathrm{gm}$ hydrolysate) & $1.02 \pm 0.05$ & $1.35 \pm 0.26$ & 10.87 & 4 & 0.43 \\
\hline
\end{tabular}

Table 3: Functional properties of Striped catfish protein hydrolysate prepared with enzymes papain and bromelain. Values represent mean \pm SD of three replicates. 


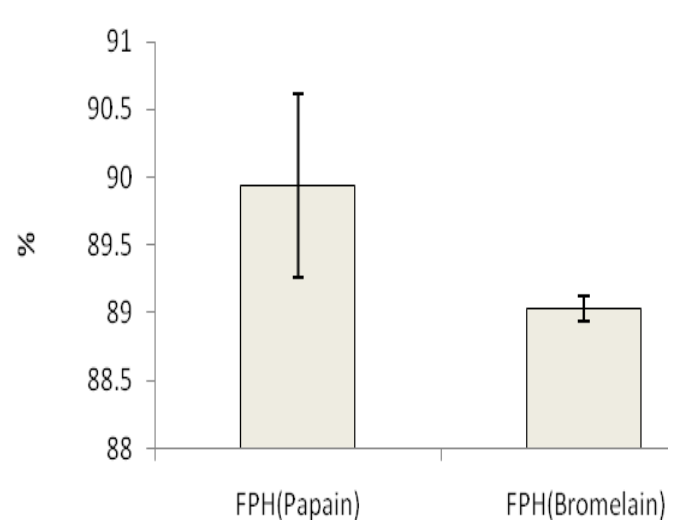

Fig 3: Effect of two different neutral proteases papain and bromelain on DPPH radical scavenging capacity (\%) of Striped catfish protein hydrolysate $(n=3, t=1.34$, $\mathrm{df}=4, \mathrm{p}=0.25$ )

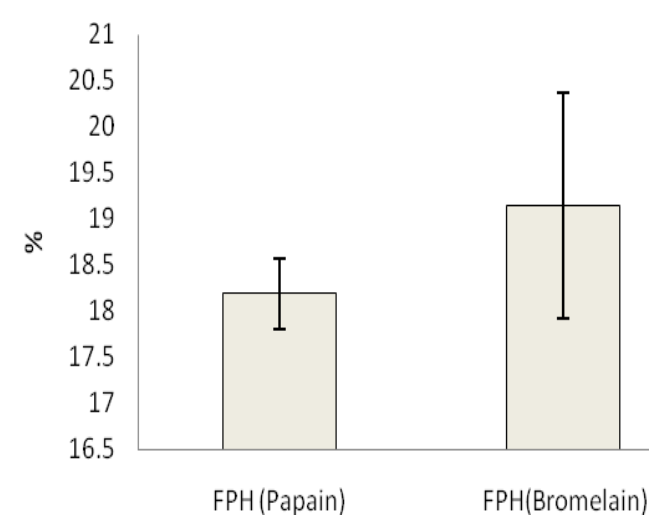

Fig 4: Effect of two different neutral proteases papain and bromelain on the metal chelating capacity $(\%)$ of Striped catfish protein hydrolysate $(\mathrm{n}=3, \mathrm{t}=0.74, \mathrm{df}=4$, $\mathrm{p}=0.50$ )

The hydrolysates show no significant difference in DPPH radical-scavenging capacity (Fig. 3), nor in metal-chelating ability (Fig. 4). The reducing capacity of hydrolysate prepared with papain was significantly different and low $(0.612 \pm 0.005 \mathrm{~nm})$ compared with that from bromelain $(0.728 \pm 0.04 \mathrm{~nm})(\mathrm{n}=3, \mathrm{t}=5.21, \mathrm{df}=4, \mathrm{p}=0.006)$. Hydrolysate from both papain and bromelain had almost 90\% DPPH radical-scavenging activity, but less than $20 \%$ metalchelating capacity.

\section{Discussion}

The study aimed to determine the difference in composition, functional properties and antioxidant activities of hydrolysates produced from the frame meat of Striped catfish using the same concentration of two neutral proteases, papain and bromelain. The same amount of solubilisation caused by the two proteases may be the reason for the insignificant difference in the degree of hydrolysis. The low degree of hydrolysis attained with both the protein hydrolysates may be because single enzymes may not be able to provide extensive hydrolysis in a reasonable period of time (Lahl \& Barun 1994). Typical yields of fish protein hydrolysates have been reported to be 10-15\%, based on fresh fish substrates (Quaglia \& Orban 1990). The low yield correlates with the low degree of hydrolysis attained by using either of the enzymes.

The low moisture content in the composition of the hydrolysates $(<6 \%)$ will contribute to the stability. Considerable fat might have been removed when the meat was cooked and as hydrolysis proceeded, the membranes might have rounded up to form insoluble vesicles, which could have allowed the removal of membrane structural lipids (Shahidi et al. 1995). These vesicles were separated from the soluble hydrolysate in the form of a pellet by centrifugation.

Glutamic acid, aspartic acid, alanine, leucine, arginine and histidine constituted the major proportion of amino acids in the hydrolysates, in agreement with many other studies (Gesualdo \& Li-Chan 1999, Thiansilakul et al. 2007). The proline content in both hydrolysates was high compared to that observed in Round Scad hydrolysate $(0.51 \%)$ (Thiansilakul et al. 2007). Proline is found to be a contributing factor to the bitterness of protein hydrolysate. On the analysis of basic tripeptides which contribute to bitterness, Hevia \& Olcott (1977) found that the tripeptides contained asparagine and lysine as the second and C-terminal residues, respectively, with the N-terminal residue leucine or glycine. Striped catfish protein hydrolysates have a comparatively high content of these amino acids. 
Amino acids such as histidine and tryptophan are known to exhibit antioxidative properties. Hydrolysate prepared from the catfish meat had good levels of histidine. The antioxidative activity of histidine or a histidine-containing peptide may be attributed to the chelating and lipid radical-trapping ability of the imidazole ring, whereas the tyrosine residue in the peptide may act as a potent hydrogen donor.

Hydrophobicity and molecular weight (Adler-Nissen 1986) mostly governs the functional properties of protein hydrolysates. The difference in solubility between the hydrolysates may be due to the difference in peptide length and the ratio of hydrophilic/ hydrophobic peptides. The high solubility of protein hydrolysate is due to the size reduction and the formation of smaller, more hydrophilic and more solvated polypeptide units. The high nitrogen solubility will impart a 'smooth' feel to the mouth when eating food that incorporates protein hydrolysates. Hydrolysates are surface-active materials and promote oil-in-water emulsion as they have both hydrophilic and hydrophobic groups. Higher contents of larger molecular weight peptides or more hydrophobic peptides contribute to the stability of the emulsion. The high emulsification capacity obtained in Striped catfish protein hydrolysates may be because of the low degree of hydrolysis attained. Excessive hydrolysis with high degree of hydrolysis brings about the loss of emulsifying properties (Kristinsson \& Rasco 2000a, Quaglia \& Orban 1990) because small peptides cannot unfold and reorient at the interface like large peptides to stabilize emulsions. Hydrolysate from both papain and bromelain had a much higher emulsifying capacity than that from Lesser sardine protein hydrolysate $(15.2 \pm 0.47 \mathrm{ml}$ oil/ $/ 0.5 \mathrm{gm}$, degree of hydrolysis $9.31 \%)$ (Souissi et al. 2007) or from shark protein hydrolysate $(30 \mathrm{ml}$ oil/ $/ 0.5 \mathrm{gm}$, degree of hydrolysis $6.5 \%$ ) (Diniz \& Martin 1997) prepared with alcalase enzymes.

The foaming capacity (Table 3) of the Striped catfish protein hydrolysates is lower than that obtained from shark protein hydrolysate at a degree of hydrolysis 6.5\% (Diniz \& Martin 1997), or from capelin protein hydrolysate (90\% at degree of hydrolysis $12 \%$ ) (Shahidi et al. 1995). Proteins in dispersion cause a lowering of the surface tension at the water-air interface, thus creating foam. Peptides produced by hydrolysis in the present study would not have been absorbed and denatured efficiently to reduce the interfacial tension enough to form the viscoelastic film required for a good foaming agent (Dickinson \& McClements 1996). The significant difference in the foaming capacities may be because of the difference in degree of hydrolysis attained with the two different enzymes. Foaming capacity depends on the duration and degree of hydrolysis (Thiansilakul et al. 2007, Diniz \& Martin 2007, Klompong et al. 2007).

The oil-binding capacity is an important functional characteristic of the ingredients used in the meat and confectionery industries, because it influences the taste of a product. The mechanism of oil absorption is attributed mostly to physical entrapment of the oil, and thus the higher bulk density of the protein, the more oil absorption. Although the substrate specificity of enzymes also plays a major role in determining oil-binding capacity (Kristinsson \& Rasco 2000), the two different proteases did not bring about a significant difference in oil-binding capacity. Hydrolysates from both enzymes had higher oil-binding capacities than that of sardine protein hydrolysate $(0.911 \pm 0.03 \mathrm{ml} / \mathrm{gm})$ at a degree of hydrolysis of $6.62 \%)$ (Quaglia \& Orban 1990) and lower than that of shark protein hydrolysate $(3.8 \mathrm{ml} / \mathrm{gm})$ at a degree of hydrolysis of 6.5\% (Diniz \& Martin 1997)

DPPH, a stable free radical, has an absorbance maximum at $517 \mathrm{~nm}$. When DPPH encounters a proton-donating substance, such as an antioxidant, the radical is scavenged and the absorbance is reduced (Shimada et al. 1992). There was no significant difference in the DPPH radical-scavenging capacities of hydrolysate from papain and bromelain, as the degree of hydrolysis was also not significantly different. It was higher than the DPPH radicalscavenging activity exhibited by lesser sardine $(41 \pm 2 \%$ : Souicci et al. 2007) and mackerel protein hydrolysates (15.14\%: Wu et al. 2003). The antioxidative activity of protein 
hydrolysates depends on the proteases and hydrolysis conditions employed. Generally, aromatic amino acids are considered to be effective radical-scavengers, because they can donate protons easily to electron-deficient radicals (Rajapakse et al. 2005). Both hydrolysates had a relatively high histidine content, which could explain the high antioxidative capacity of the hydrolysate. The result showed that the Striped catfish hydrolysates contain substances which are electron donors, which react with free radicals to convert them to more stable products and terminate the free-radical chain reaction.

The metal-chelating ability of hydrolysates differs with the kind of enzyme used (Klompong et al. 2007), but those in the present study were not significantly different. Transition metals such as $\mathrm{Fe}, \mathrm{Cu}, \mathrm{Co}$, in foods will act as pro-oxidants and breakdown hydroperoxide to volatile compounds. They react very quickly with peroxides by acting as oneelectron donors to form alkoxyl radical. Peptides in hydrolysates can chelate pro-oxidants, due to an increased concentration of carboxylic groups and amino groups in branches of the acidic and basic amino acids leading to decreased lipid oxidation (Sherwin 1990) in food systems. This improves the safety and stability of the food product.

Reducing power is a measure of antioxidant capacity. In the reducing capacity assay, the colour of the test solution changes from yellow to green to blue, depending on the reducing power of each compound present in the hydrolysate. The significant difference in the reducing capacities of hydrolysates prepared with the two different enzymes may be due to the substrate specificity of enzymes (Cumby et al. 2008). The reducing capacity of Striped catfish protein hydrolysates is comparable with that obtained with Yellow stripe travelly (Selaroides leptolepis) protein hydrolysates at 5\% degree of hydrolysis (Klompong et al. 2007). Reducing capacity can also vary with the concentration of hydrolysates.

We conclude that the hydolysates produced from Striped catfish frame meat differed significantly according to which enzyme was used in preparing them, which also led to differences in protein and ash content. The functional properties (foaming and emulsification capacities, peptide solubility) also differed significantly in hydrolysates from the two enzymes, as did the reducing property. The study showed that Striped catfish protein hydrolysates have desirable functional and antioxidant properties. Hence protein hydrolysates made from Pangasianodon hypophthalmus can be used not only as a food additive to improve functionality, but also for improving the nutritional profile and protein quality by incorporating them in selected foods. This finding is important because Striped-catfish farmers, especially those of Andhra Pradesh (India), are facing a setback because of the low price realised for the fish in the market. One of the reasons attributed for the low price is the yellow colour of the meat. Thus the potential of Striped catfish meat to be converted into high-end products such as protein hydrolysates will help farmers realise better prices for their produce.

\section{Acknowledgements}

The authors are grateful to the Director of Central Institute of Fisheries Technology for granting permission to carry out the work and for providing the necessary facilities. Indian Council of Agricultural Research provided the funding for the work. The authors also thank Dr. P.K Binsi, Scientist, CIFT for valuable suggestions.

\section{References}

Adler-Nissen J (1986) Enzymic hydrolysis of food proteins. Elsevier Applied Science, London

AOAC (2000) Official methods of analysis. Association of Official Analytical Chemists International, Washington DC USA

Benjakul B \& Morrissey MT (1997) Protein hydrolysates from Pacific whiting solid wastes. Journal of Agricultural and Food Chemistry 45: 3424

Cumby N, Zhong Y, Nazck M \& Shahidi F (2008) Antioxidant activity and water holding capacity of canola protein hydrolysates. Food Chemistry 109(1): 144-148 
Decker EA \& Welch B (1990) Role of ferritin as a lipid oxidation catalyst in muscle food. Journal of Agricultural \& Food Chemistry 38: 674-677

Dickinson E \& McClements DJ (1996). Molecular basis of protein functionality. pp 27-80 in: Advances in food colloids. Blackie, Glasgow, UK,

Diniz FM \& Martin AM (1997) Effects of the extent of enzymatic hydrolysis on functional properties of shark protein hydrolysate. Lebensmittel-Wissenschaft \& Technologie 30: 266-272

Hevia P \& Olcott HS (1977) Flavour of enzyme-solubilized fish protein concentrate fractions. Journal of Agricultural \& Food Chemistry 25(4): 772-779

Ishida Y, Fugita T \& Asai K (1981) New detection and separation method for amino acid by high performance liquid chromatography. Journal of Chromatography 204: 143-148

Klompong V, Benjakul S, Kantachote D \& Shahidi F (2007) Antioxidative activity and functional properties of protein hydrolysate of yellow stripe trevally (Selaroides leptolepis) as influenced by the degree of hydrolysis and enzyme type. Food Chemistry 102: 1317-1327

Kristinsson HG \& Rasco BA (2000a) Fish protein hydrolysates: production, biochemical and functional properties. Critical Reviews in Food Science \& Nutrition 40(1): 43-81

Kristinsson HG \& Rasco BA (2000b) Biochemical and functional properties of Atlantic salmon (Salmo salar) muscle proteins hydrolysed with various alkaline proteases. Journal of Agricultural \& Food Chemistry 48(3): 657-666

Lahl WJ \& Barun SD (1994) Enzymatic production of protein hydrolysates for food use. Food Technology 48: $68-71$.

Lawhon JF, Carter CM \& Matil KF (1972) A comparative study of the whipping potential of an extract from several oil seed flours. Cereal Science Today 17: 240-244.

Liceaga-Gesualdo AM \& Li-Chan ECY (1999) Functional properties of fish protein hydrolysate from Herring (Clupea harengus). Journal of Food Science 64(6): 1000-1004

Morr CV, German B, Kinsella JE, Regenstein JM, Van Buren JP, Kilara A, Lewis BA \& Mangino ME (1985) A collaborative study to develop a standardized food protein solubility procedure. Journal of Food Science 50: $1715-1721$

Quaglia GB \& Orban E (1990) Influence of enzymatic hydrolysis on structure and emulsifying properties of sardine (Sardina pilchardus) protein hydrolysate. Journal of Food Science 55: 1571-1573

Rajapakse N, Mendis E, Jung WK, Je JY \& Kim SK (2005) Purification of a radical scavenging peptide from fermented mussel sauce and its antioxidant properties. Food Research.International 38: 175-182.

Sathivel S, Bechtel P, Babbitt J, Smiley S, Crapo C \& Reppond K1 (2003) Biochemical and functional properties of herring (Clupea harengus) byproduct hydrolysates. Journal of Food Science 68: 2196-2200.

Shahidi F, Han XQ \& Synowiecki J (1995) Production and characteristics of protein hydrolysates from capelin (Mallotus villosus). Food Chemistry 53: 285-291

Sherwin ER (1990). Antioxidant. pp 139-193 in: AL Branen, PM Davidson \& S Salminen (Eds.) Food additives. Marcel Dekker, New York, USA.

Shimada K, Fujikawa K, Yahara K \& Nakamura T (1992). Antioxidative properties of xanthan on the autoxidation of soybean oil in cyclodextrin emulsion. Journal of Agricultural \& Food Chemistry 40: 945948.

Souissi N, Bougate A, Triki-Ellouz Y \& Nasri M (2007) Biochemical and functional properties of Sardinella (Sardinella aurita) by-product hydrolysates. Food Technology \& Biotechnology 45 (2): 187-194

Swift CR \& Sulzbacher WL (1963) Comminuted meat emulsions: factors affecting meat proteins as emulsion stabilizers. Food Technology 17(2): 224-226

Thiansilakul Y, Benjakul S \& Shahidi, S (2007) Compositions, functional properties and antioxidative activity of protein hydrolysates prepared from round scad (Decapterus maruadsi). Food Chemistry 103: 1385-1394

Wu HC, Chen HM \& Shiau CY (2003) Free amino acids and peptides as related to antioxidant properties in protein hydrolysates of mackerel (Scomber austriasicus). Food Research International 36: 949-957

Yildirim A, Mavi A \& Kara AA (2001) Determination of antioxidant and antimicrobial activities of Rumex crispus L. extracts. Journal of Agricultural \& Food Chemistry 49: 4083-4089. 


\section{الملخص العربى}

التركيب والصفات الوظيفية والنشاط المضاد للأكسدة لبعض المواد التى تذوب فى الماء والمحضرة من لحوم أسماك القط (باتجاسيانودون هيبوفثالميس)

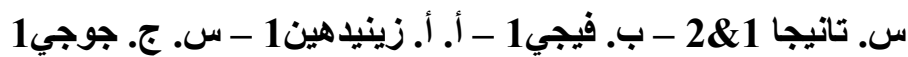

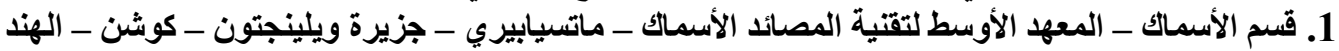
2. قسم الأبحاث الزراعية (سيدات) - ميدان بهارشتبير - شارع نادان كانان خانداجيري - باراميندا - بهيبانيسيار - الهند

لقد زادت أهمية سمكة القط المخططة (بانجاسيانودون هيبوفثالميس) لاستخدامها فى المزارع السمكية فى الهند. ونظرا لانتشارها

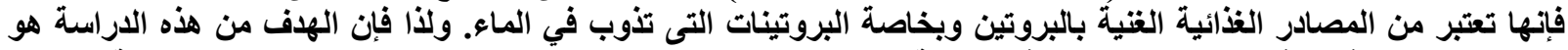

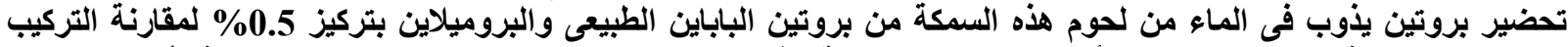

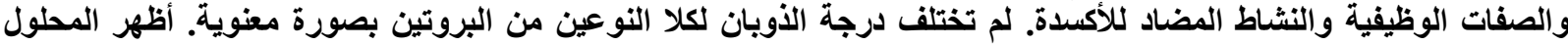

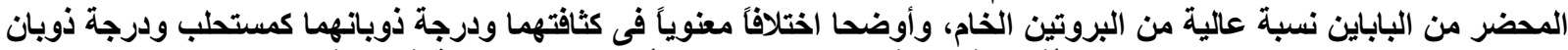

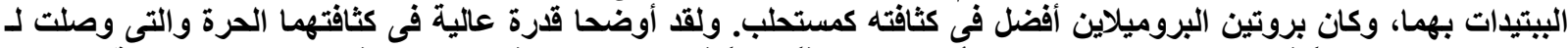

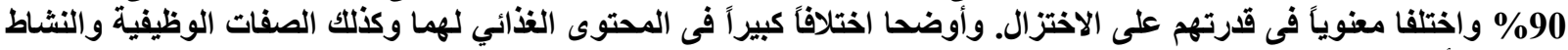

